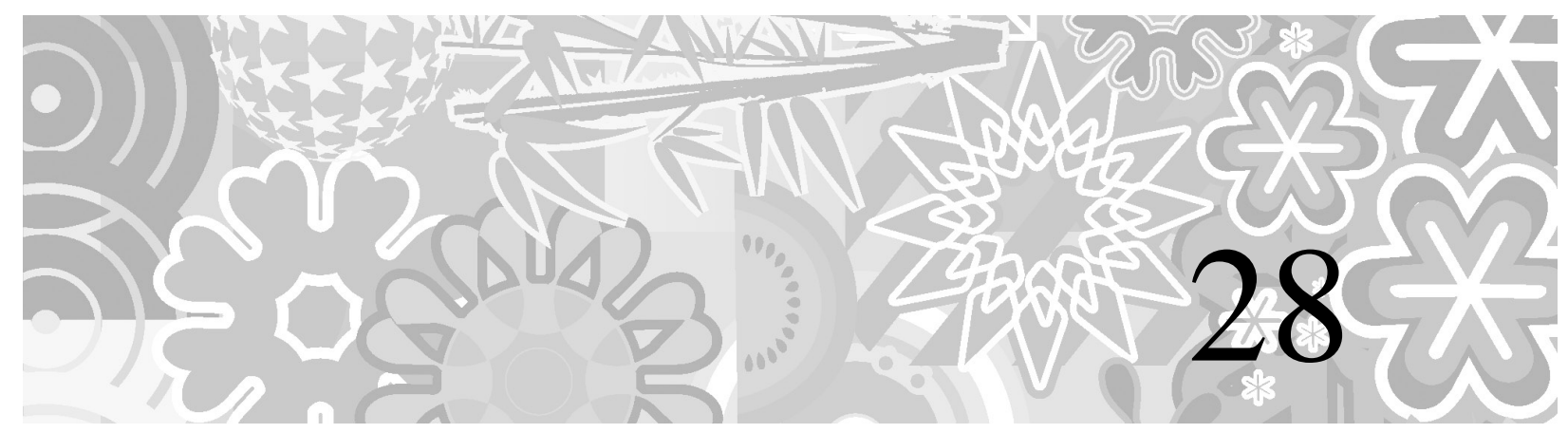

\title{
Media and Communications Regulation and Child Protection: An Overview of the Field
}

\author{
David Oswell
}

\section{INTRODUCTION}

In an age when there is a plurality of content providers, in a system of media abundance, and with an increasing uncertainty to centralized regulatory monopolies, how are children to be protected from harm and illegalities, without chilling the creative heat of invention and new synergies? In this chapter, I look to the broader historical context and then to contemporary discussion about regulation. I provide an overview of some significant aspects of the current landscape concerning legislative discourse, regulatory agency and methodology. My discussion focuses on media and communications regulation and child protection in the USA and European Union, primarily the UK, and, by and large, I focus on the regulation of 'content', rather than on 'contact'.

\section{SOME HISTORICAL ISSUES}

Historically, media and communications (including newspaper, magazine and book publishing, theatre, radio, cinema, television, video, and telecommunications) have been regulated in the context of the nation state (namely, national jurisdiction concerning content, access, and competition and international treaties concerning trade and technological standards). Governments, regulatory agencies, industry bodies, academics, religious organizations, moral arbiters, and 'responsible' persons have made decisions concerning the role of media and communications in the lives of children inasmuch as the systems of distribution and the content distributed could be controlled and shaped in such ways to maintain and facilitate the well-being of the national population. By and large, concern 
focused on understandings of children as impressionable and easily influenced either by the type of media content or by the technology itself. Thus, in the nineteenth century, religious societies in England produced magazines initially aimed at the poor, encoding the moral values of the middle class, containing stories about zealous missionaries in foreign lands or pious and poverty stricken children in the heart of depraved London (Drotner, 1988). But equally in the mid- to late-nineteenth century, the penny dreadfuls which drew from the gothic novel and grim tales of characters, such as Sweeny Todd and Varney the Vampire, and which were popular with a newly literate workingclass juvenile population - gathered a mass readership and gave the established English middle class cause for concern (Pearson, 1983). In the 1940s and 1950s, concern about the dangerous influence of comic books on young people fed into US Senate hearings. Psychiatrists reported on the effect of some comic book stories on the mental stability of children (Wertham, 1954). In the UK, similar concerns were articulated, not simply around the problem of violence, youth, and popular culture, but on the pathologization of 'horror comics' as a peculiarly US phenomenon. Thus, moral panic about comic books in the UK was explicitly anti-American and partly orchestrated by the Communist Party of Great Britain (Barker, 1984a). The campaign led to the Children and Young Persons (Harmful Publications) Act of 1955, which was applied to publications ('mainly of stories told in pictures') portraying 'the commission of crimes', 'acts of violence or cruelty', and 'incidents of a horrible or repulsive nature' that 'would tend to corrupt a child or young person' (quoted in Newburn (1992)). Sociologists have argued that public anxiety about the moral regulation of society tends to occur during times of social crisis at particular historical conjunctures. Demands for public order have been understood either as genuinely emerging from the people or as an 'authoritarian populism' orchestrated by elite political and social groups (Hall et al., 1978; Goode and Ben-Yehuda, 1994).
Ideological standpoints and misconceptions have plagued debates about media and communications regulation across Europe and the USA. In the 1950s and early 1960s the television western became a focus of political and popular regulatory discussion. In the USA, the western and the ideology of the 'wild west frontier' were seen to parallel the scientific progress of the NASA space programme (Cross, 1997). But in the UK, Gunsmoke, Maverick, Roy Rogers, Hopalong Cassidy and others were seen as commercial, ‘American' and a source of social violence and were the subject of lengthy discussion by the Pilkington Committee on broadcasting (Oswell, 2002). A fresh focus in the press and parliament on their imitative affect on young people committing suicide by hanging helped establish the conservative Christian pressure group, the National Viewers and Listeners Association (NVLA) led by Mary Whitehouse. The NVLA was particularly vocal in public regulatory discourse from the 1960s onward, calling for greater restrictions on the distribution of sexual, violent and non-Christian content on television, video, and cinema (Tracey and Morrison, 1979). With respect to broadcast television, much academic research, with the exception of a number of experimental and laboratory investigations, has from the late 1950s onward demonstrated largely that its influence is dependent on the nature of the programme, the psychological development, disposition and cognitive capacity of the child, the social and emotional economy of the family, interpersonal peer relations, and the broader discursive context (Luke, 1990). The US Surgeon General's Advisory Committee on the impact of television violence gathered evidence and deliberated on the matter in the 1970s. Caught up in the different political, industry, and academic interests, the conclusions were inconclusive (Rowland, 1997).

Nevertheless, throughout much of the postwar period the issue of media violence dominated the discussion and framing of media regulation. Some critics have argued that moral panics and media regulation have 
been responses to the 'newness' of new media technologies (Drotner, 1992; Livingstone, 2002); others have argued that they are cyclical responses to generational difference (Pearson, 1983; Barker, 1984b). In the early 1980s there was a notable public concern with 'video nasties' in the UK. There were various calls from the press, child experts, religious organizations, and others for the regulation of the video rental and domestic purchasing market. The Video Recordings Act of 1984 introduced the statutory classification of video under the charge of the, then, British Board of Film Censors (BBFC). After the murder of a 2-year-old James Bulger in 1993, a similar collection of social actors called for further regulation of the video market. It would be correct to say that (despite moments of 'panic' and wide public discussion), far from being a response to 'new' media, anxiety about the adequacy of media regulation (whether framed in moral, religious, or psychological terms) has been an ongoing feature of modern media regulatory discourse and that much of that anxiety has been focused on the relations between imaging technology, violence, and young people.

In the early to mid-1980s, concern about commercial culture - that had been ongoing as a significant regulatory issue since the mid-1950s, if not before - had become focused on the problem of advertising and marketing to children. A particular issue was the relation between television programming and toy merchandising. From its beginning in the 1940s and 1950s, children's television in the USA (e.g. Davy Crockett) and UK (e.g. Muffin the Mule) had merchandising tie-ins (Cross, 1997; Oswell, 2002). Yet it was the distribution of the animation $\mathrm{He}$ Man and the Masters of the Universe in 1983 that galvanized a huge debate in the USA and elsewhere. The toy manufacturer Mattel, which had produced a range of 'Masters of the Universe' dolls since 1974, licensed the concept to the animation company Filmation. Both toy range and television animation were hugely successful. Prior to that, in 1969, the Federal Communications Commission (FCC), the US media and communications regulator, had acted against a similar merchandising deal concerning Mattel's 'Hot Wheels' toy car range and a television animation of the same name and had referred to this as 'disturbing' inasmuch as it 'subordinates programming in the interest of the public to programming in the interest of its saleability' (FCC, 1969: 149). But during the period of the Reagan government, the head of the FCC, Mark Fowler, declared that broadcasters should not be held responsible for children's culture and that television should operate as a free market (Kunkel and Watkins, 1987; Herman and McChesney, 1997). In the 1980s, the bestselling toys in the USA were marketed through 'programme-length commercials', including G.I. Joe, Thundercats (Hasbro toys), Care Bears, and Strawberry Shortcake (Kenner) (Cross, 1997). In 1985 the FCC stated that 'the profit-sharing arrangement is an innovative technique to fund children's programming ... [and] we should have diversity in the method of financing that programming' (FCC, 1985: 713). This worrying trend was the object of much public criticism, most notably by the campaigning group Action for Children's Television in the USA, headed by Peggy Charren. By the late 1980s and early 1990s, FCC policy shifted away from the harsh deregulatory principles of the Fowler regime to more sanguine attempts to limit the perceived negative influences of advertising and marketing.

At the heart of the debate about television merchandising were concerns that children's media culture would become thoroughly commercialized, that the best interests of the child would not be served, and that children's media might itself disappear as a distinct market. In the USA, the Television Act of 1990 limited the amount of advertising per hour, stipulated that a condition of television station licence agreements should be that they serve the "educational and informational needs of children', and stated that broadcasters needed to air a minimum of 3 hours of educational programmes to meet the needs of children under the age of 16 (Jordan, 1999). Similarly, in the UK, 
but also in other European countries, there was sustained debate from the mid-1980s to the 1990s about the quality and quantity of children's television. The traditions of public service broadcasting (of which children's broadcasting was seen to be a key aspect) were seen to be threatened by a deregulated commercial television market. Initially, there were demands made to government and regulators to protect the provision of children's television (Broadcasting Act of 1990 in the UK), but, as with the USA until quite recently, instead of seeing a drop in the quantity of children's television programming, a more competitive, liberalized, internationalized, multi-platform television market has produced an increase in provision. In this context, the concern about the quality of children's television programming has been defined in terms not simply of educational programming, but more broadly of a diversity of children's television output and its ability to meet the needs and interests of children (Davies and Corbett, 1997; Blumler and Biltereyst, 1998).

\section{AFTER SOVEREIGNTY: FROM SCARCITY TO ABUNDANCE?}

A major theme in current regulatory debate is that we are now living in an age of abundance, increasingly global, and with more horizontal relations between production and consumption. Much of this discourse has been simmering over the last 30 years (initially in relation to video, satellite and cable technology), but recent discourse (since the early 1990s) has been typified by a technological and paradigm shift from 'terrestrial broadcast television' to 'broadband digital internet connectivity'. Thus, John Perry Barlow, co-founder of the Electronic Frontier Foundation, heralds a new 'global and antisovereign' space that has the capacity to regain freedoms lost to broadcast media and its censorial 'standards of purity', 'undo all the authoritarian powers on earth' and is 'too widespread to be easily dominated by any single government' (Barlow, 1996a: 56). Even a cursory glance at some of the central regulatory issues concerning children over the last 200 years suggest that such a typification of the changing media and communications regulatory environment presents a severely limited and myopic vision.

A significant moment in European regulatory discourse and policy is the publication in 1994 by an expert group of the European Commission. The Bangemann report (High Level Group on the Information Society, 1994) considered, what was then called, the 'information society'. It made visible existing media and communications as a network of networks, not only within member states, but also across Europe as a networked region. In concert with other dominant policy discourses at the time, synergy across national boundaries and across industrial sectors was seen as central to the development of national and European information economies. There was seen to be a need for policy-makers to be aware that greater competitive advantage relied on a greater confluence between historically distinct industries, such as computing, broadcasting, and telecommunications. The technology that was seen to symbolize such confluence was the internet, but the platform, or model, upon which such communication across sector and national boundaries was materially based was that of telecommunications (Hills and Michalis, 1999; Melody, 2003: 9). Telecommunication networks provided the infrastructure for highcapacity data transfer between governments, businesses, organizations, and homes. Media industries historically with a high level of vertical integration (i.e. from transmission infrastructure to production to service and content provision), such as broadcasting, now faced increasing uncertainty with regard to that value chain. Moreover, the governance and regulation of the information society was predicated, not on a broadcasting model that foregrounded matters of content, but on a telecommunications model that was based on competition. The Bangemann report helped set the agenda for European regulatory policy for the ensuing years.

In conditions of convergence, standardized languages and terminologies are adopted in 
order to provide structures of intelligibility and translation across historically different media and communications industries. In the past, regulation of media and communications with regard to questions of the protection of children has been dependent on an understanding of the difference between different media technologies, delivery and distribution systems, and generally different industrial contexts. Thus, the regulation of cinema was different from that of television and required a different regulatory agency and a different set of skills and competencies. Even, if the regulation of different media was to be housed within the same regulatory agency (such as the FCC in the USA), the different media were treated as different regulatory objects. Today, though, although there is still an understanding of differences across media, the principle for their regulation is often stated in terms of uniformity and standardization (Melody, 2003). We should be wary, though, of assuming that (although there are moves toward regulatory convergence) contemporary media and communications are now simply governed according to a new set of principles and mechanisms completely different from those within older media and communications environments. Richard Collins, for example, has distinguished between three modes of governance for internet communications: hierarchical, market and network governance. Collins (2006: 20) argues that the phenomenal takeup of internet communications does not imply a simple shift in mode of governance, namely to one predicated on networked, or self-regulated, governance; rather there is 'a flexible and shifting articulation of different modes of governance, market, hierarchy and network'.

The shifting allegiances to historic industryspecific regulatory terminologies, paradigms and resources help to shape contemporary understandings of media and communications regulation with regard to children. Most notably, '[t]elecommunications operators are not normally held responsible for the content of messages or services that they carry across their networks', whereas, in contrast, 'broadcasting has ... been traditionally highly regulated' (Campbell and Machet, 1999: 142). Telecommunications operators have been viewed as 'common carriers', whereas broadcasters have been construed as publishers of content. In the mid- to late1990s the language of responsibility was central to the governance of internet service providers (ISPs): should they be liable for content accessible via their service provision or not? Whatever the veridicality of claims concerning technological neutrality and market convergence, regulatory agencies construct such convergence as a regulatory objective. Thus, for example, ex-head of content regulation at Ofcom, Richard Hooper (2005: 4) states that: ' $[\mathrm{t}] \mathrm{he}$ regulation of communications should aspire to be technology and platform neutral, as set out in the European Directives on telecommunications regulation. Yet in practice, achieving technology neutrality can be very difficult to do'. Instead of assuming asymmetries between technologies as obstacles to regulation, they provide the incentives for intended resolutions (whether in terms of convergence or harmonization or the marking of regulatory boundaries between different sectors and industries) and constitute the basis of ongoing problematization. Such an understanding of media and communications regulation does not presume the absolute decline of national sovereign institutions, nor of a simple abundance of capacity and content. As Brian Loader has argued, although new digital broadband networked technologies facilitate 'new forms and expressions of governance' ('a paradigmatic change in the constellation of power relations between individuals, governments and social institutions'), they do not give rise to 'an uncontested domain and the stakeholders in the politics of the modern nation-state are not so easily displaced' (Loader, 1997: 1-2). Any sociology of media and communications regulation needs to account not only for the rhetoric of change, but also for its mobilization and institutionalization by interested and embodied social actors. 


\section{REGULATORY OBJECTIVES AND STATUTORY LEGISLATION}

Some commentators have been sceptical of claims about new communication technologies bringing about new forms of criminality and, hence, have been critical of calls for new regulatory codification and legislation. For some, the internet is simply a vehicle for existing criminal behaviours (Williams, 2004). David Wall has argued that the term 'cybercrime' 'has no specific referent in law', that it is a notion 'largely invented by the media' and that, 'despite the rather unsystematic attempts to define it, the term nevertheless invokes a knee-jerk response from the media, policymakers, politicians, academics and the public alike' (Wall, 2001: 2). Such an understanding serves itself to invoke earlier Luddite reactions to the perceived risks of new media and communication technology, in a manner similar to that of sociological accounts of media panics (Drotner, 1992). Although the rhetoric of 'cybercrime' may be unhelpful, it nevertheless signals the mobilization of social actors, the development of new regulatory terminologies, and the invention of new regulatory codification and legislation in the context of perceived new or developing forms of criminality. It is in this sense that new legislation and regulatory codification must be taken seriously and analysed as sociologically significant.

Regulatory and legislative responses to internet communications have been wide-ranging, but also noticeably tempered by national and regional differences. The European Commission from the start had an understanding that 'over-hasty legislation should be avoided' (Commission of the European Communities, 1996a) and that, in the first instance, greater cooperation was needed across different national governments, law enforcement agencies, and cultures of the European Union. Any move toward greater harmonization would need to surpass existing definitions of illegalities across the different jurisdictions of the different member states. Nevertheless, although the European Union already had in place existing commitments to cooperation regarding justice and home affairs, proposals were made for greater harmonization of new national legislation regarding the internet (Campbell and Machet, 1999). Rather than seeking, in the first instance, European-wide formal regulatory structures regarding illegal content, the European Commission recommended moves toward greater industry self-regulation and greater parental responsibility in the domestic regulation of their children (Commission of the European Communities, 1997: 30). The responsibility for formulating legal definitions of 'cybercrime' was thus left to decision-makers and law-makers in particular national contexts. Moreover, early in the discussion, the European Commission clearly differentiated between two concerns (illegal content, which 'may be banned for everyone, regardless of the age of the potential audience or the medium used' and harmful content, which 'might affect the physical and mental development of minors' and which should be 'allowed only for adults' (Commission of the European Communities, 1996b: 6)) and defined 'different legal and technological responses' (Commission of the European Communities, 1996c: 10). In doing so, they reduced the horizon of illegalities to that of images of child sexual abuse, race-hate material and extreme violent pornography, and thus radically realigned and rearticulated historic concerns and criteria (concerning harm, offence and obscenity) established with regard to older media, such as broadcast television, film and video (which had institutionalized responses to harm in the context of notions of the socially, emotionally, cognitively and physically developing child). Such a considered and strategic approach initially allowed a high degree of local interpretative flexibility. Needless to say, it was this strategy that was also pursued by other national governments (e.g. the Australian Broadcasting Authority's focus on 'contact and safety issues', 'illegal content', and 'unsuitable content' (Grainger, 1998: 18)).

In the UK there has been legislative reform. Thus, regarding the issue of child pornography and obscenity, the Criminal 
Justice and Public Order Act of 1994 amended the Protection of Children Act of 1978 so as to include reference not only to photographs, but also 'pseudo-photographs' (see Oswell (2006)). The act refers not only to actual images, but also to 'data' that may be 'converted' into an image. It implicitly encodes a principle of technological symmetry or neutrality, inasmuch as a “ "[p]seudo-photograph" means an image, whether made by computergraphics or otherwise howsoever, which appears to be a photograph'; and it constructs childhood not straightforwardly as defined by age (originally 16 years, but increased to under 18 years by the Sexual Offences Act of 2003), but as an 'impression', such that:

[i]f the impression conveyed by a pseudophotograph is that the person shown is a child, the pseudo-photograph shall be treated for all purposes of this Act as showing a child and so shall a pseudo-photograph where the predominant impression conveyed is that the person shown is a child notwithstanding that some of the physical characteristics shown are those of an adult.

Similar versions of this legal formulation are found in other jurisdictions (e.g. 163.1 (1) of the Criminal Code in Canada). Legislation concerning child pornography across member states of the European Union indicates greater standardization in recent years, compared with the significant differences (for example, regarding age of maturity and severity of punishments with respect to possession, distribution, or production) in past years.

Definitions of 'harmful content' are wideranging. Some commentators seem to have interpreted the European Commission policy regarding 'harmful content' as by definition referring to material that is not illegal (Akdeniz, 2001: 304). Such an understanding frames 'harm' within a definitional context different to that of prior legislation and regulation concerning radio, television, film, and video. Bad language, promotion of drugs and alcohol, and overly violent and sexually explicit content has been consistently prohibited from broadcast terrestrial and nonencrypted satellite and cable television in the UK, whether governed by the BBC Board of Governors or Ofcom (or its predecessors).
Similarly, the British Board of Film and Video Classification (BBFC) has regulated video (in the context of the Video Recordings Act of 1984) according to the criterion of 'harm' and particularly with respect to children and other vulnerable people. The Williams Committee Report on Obscenity and Film Censorship (1979), although never translated into legislation, sought to restrict offensive material, but to prohibit material seen to cause harm. Williams stated that 'no conduct should be suppressed by law unless it can be shown to harm someone' (quoted in Newburn (1992: 182)). Historically the categorical differentiation between material likely to cause offence and that likely to cause harm has been significant in media and communications regulation. Despite persistent calls in the 1990s to reform obscenity legislation, the UK has not redefined legal understandings of obscenity in the context of internet communications, but only extended the notion of obscenity - as that whose tendency is to deprave and corrupt to include computer-generated content. The Obscene Publications Acts of 1959 and 1964 criminalize the publication and distribution of obscene content, but they are inadequate to the task of regulating obscene content on the internet, not least because providers of such material may well be based outside the reach of UK jurisdiction. Moreover, although the downloading of internet child pornography constitutes a criminal offence, possession of obscene material has yet to be criminalized. Similarly, in contrast to policing and prosecutions relating to the downloading of child pornography, there have been very few cases with regard to obscene internet publications (Akdeniz, 2001). Discussion concerning the revised European Commission Television Without Frontiers Directive has sought to address the issue of 'harmful' content, but fails to tackle the problem of convergence properly (Commission of the European Communities, 2005).

Thinking in this area is fast changing and historic concerns about 'content' are increasingly constructed and contextualized with concerns about 'contact'. Looking to 
growing concerns in Japan and the USA, the realization that mobile telephony and internet technologies were being used by adults for inappropriate, sexualized, and abusive contact with children (Childnet International, 2004) has led to the questioning in the UK of existing legislation. The Indecency with Children Act of 1960 had made reference to 'incitement' to commit a sexual offence with a minor, but many professionals in the field (including government ministers, civil servants, judges, police and non-governmental organizations) argued that the use of the internet for 'grooming' and 'luring' young people was not adequately addressed (Childnet International, 2001; Gardener, 2003). The Sexual Offences Act of 2003 now criminalizes indecent text messaging and online and offline grooming of minors. Similar legislation can be found, for example, in Australia, Canada, New Zealand and the USA (Childnet International, 2001).

In contrast to European governance and legislation, US administrations have met with much resistance (from civil liberty groups, the sex entertainment industry, and others) over attempts to introduce legislation regarding obscenity and indecency on the internet. In early 1996, the Communications Decency Act (CDA) was introduced. The act had intended to criminalize whomever knowingly used a telecommunications device to make, create, solicit or initiate the transmission of material which is 'obscene, lewd, lascivious, filthy, or indecent, with intent to annoy, abuse, threaten, or harass another person', which is 'obscene or indecent, knowing that the recipient of the communication is under 18 years of age', and the use of an 'interactive computer service to display in a manner available to a person under 18 years of age, any comment, request, suggestion, proposal, image, or other communication that, in context, depicts or describes, in terms patently offensive as measured by contemporary community standards, sexual or excretory activities or organs' (Sections $223(\mathrm{a})(1)(\mathrm{A})$ and $(\mathrm{B})$, and $(\mathrm{d})(1)(\mathrm{B}))$. The act was appealed by the American Civil Liberties Union (ACLU) in June 1996, taken to the Supreme Court in March 1997, and overturned in June 1997. The Supreme Court held that the CDA provisions of 'indecent transmission' and 'patently offensive display' abridged the freedom of speech protected by the First Amendment. Among other things, the Supreme Court stated that the CDA:

\begin{abstract}
fails to provide any definition of 'indecent' and omits any requirement that 'patently offensive' material lack socially redeeming value; neither limits its broad categorical prohibitions to particular times nor bases them on an evaluation by an agency familiar with the medium's unique characteristics; is punitive; applies to a medium that, unlike radio, receives full First Amendment protection; and cannot be properly analyzed as a form of time, place, and manner regulation because it is a content-based blanket restriction on speech (Reno v ACLU, June 26 1997, Syllabus (b)).
\end{abstract}

In the earlier appeal, it had been stated that, unlike the FCC's regulation of cable and dialup programming with regard to indecency, the CDA had failed to provide consideration of context in terms of 'the particular medium from which the material originates and the particular community that receives the material' (ACLU v Reno, June 11 1996). It had stated that '[1]aws regulating speech for the protection of children have no limiting principle, and well-intentioned law restricting protected speech on the basis of its content is, nevertheless, state-sponsored censorship' (ACLU v Reno, June 11 1996). Unlike some other media, the internet was seen by both courts as a vast, open, global, geographically non-localized medium that was nevertheless seen to be non-invasive: 'the content on the Internet is as diverse as human thought' (929F Supp at 8422). The government had argued that its 'patently offensive' standard was not vague as it accorded with the decision of Miller $v$ California. In that earlier case in 1973, it had been decided that the test for obscenity was as follows:

(a) whether the average person applying contemporary community standards would find that the work taken as a whole, appeals to the prurient interest; (b) whether the work depicts or describes, in a patently offensive way, sexual conduct specifically defined by the applicable law; and (c) whether the work, taken as a whole, lacks serious literary, 
artistic, political, or scientific value' (quoted in Reno v ACLU, June 26 1997).

The Supreme Court argued that reference to 'prurient interest' and 'serious literary, artistic, political, or scientific value' properly limited the breadth of that earlier decision. Moreover, and importantly, the Supreme Court argued that the second criterion 'absent in the CDA, allows appellate courts to impose some limitations and regularity on the definition by setting, as a matter of law, a national floor for socially redeeming value' (Reno $v A C L U$, June 26 1997). The Supreme Court held that the CDA would impact upon 'large amounts of nonpornographic material with serious educational or other value': 'the "community standards" criterion as applied to the Internet means that any communication available to a nation-wide audience will be judged by the standards of the community most likely to be offended by the message' (Reno $v A C L U$, June 26 1997). It gives the example of a parent sending their 17-year-old child at college in another state some birth control information and the parent being open to prosecution, not because either the parent, the child, or the home state would deem the material indecent or patently offensive, but because the college town community might do so.

The Child Online Protection Act (COPA) 1998, which sought to restrict the distribution of materials that are harmful to minors, was also appealed soon after its signing. The US Court of Appeals for the Third Circuit in June 2000 (ACLU v Reno, 99-1324, June 22 2000) held that - although the government had tried to learn the lessons of the Supreme Court declaration regarding the unconstitutionality of the CDA and Congress was 'cognizant of the fact that "the application of community standards in the context of the Web is controversial"" - there was not sufficient account that "[u]nlike a "brick and mortar outlet" with a specific geographic locale, and unlike the voluntary physical mailing of material from one geographic location to another, as in Miller, the uncontroverted facts indicate that the Web is not geographically constrained'. The Court of Appeals did not accept the argument that 'community standards' should be understood not as a 'geographic standard', but as an 'adult standard'. The Court of Appeals stated that with reference to existing case law 'community standards have always been interpreted as a geographic standard without uniformity' and that such a notion is to be understood in terms of 'a localized geographic content'. COPA would have made internet content subject to the most conservative community standard and to the most conservative interpretation of what is deemed harmful to minors. Such legislation would, the Court of Appeals argued, put an 'overreaching burden and restriction on constitutionally protected speech'. Whatever the final outcome of this legislation, there are considerable problems with regard to any definition of obscenity that relies on a notion of 'community standards' in the context of internet communications and of multi-cultural, multi-faith, multi-ethnic communities (howsoever formed) with different values and levels of tolerance.

Even attempts to legislate against images of child sexual abuse have been forlorn. The Child Pornography Prevention Act of 1996 (CPPA) was seen to be 'overbroad' and 'unconstitutional' in relation to two provisions. First, the act was seen to be inconsistent with Miller $v$ California on the grounds that it failed to take account of the 'community standards' criterion and that it criminalized speech without regard to the specificity of time, place or manner. Thus, for example, an online filmic version of Romeo and Juliet, in which the two young lovers are played by adult actors, might be deemed illegal on the basis of the content alone, without due regard to the artistic value of the work. It was argued that the act would criminalize sexualized images of children even though no child might be involved in the production of those images and hence contrary to the decision of the New York $v$ Ferber case, which only prohibited child pornography on the grounds that it records an actual abuse of a child. Thus, the CPPA, it was argued, would criminalize, for example, images of an adult having sexual conduct with another adult 
dressed up as a child. Moreover, if the image of sexual conduct with a child is not real, but fabricated or virtual, then it was argued that it should not be prohibited on the grounds that it cannot be deemed to have harmed a child in its production nor necessarily able to harm a child through its affect (i.e. as a method of enticement or as behaviour forming). It was argued that prohibition of content cannot be on the basis of a consequentialist argument (i.e. that certain things happen as a consequence of certain content). Second, the act was deemed overbroad and unconstitutional with respect to its criminalizing the advertising and marketing of content that 'conveys the impression' of 'a minor engaging in sexually explicit conduct' (US Court of Appeals for the Ninth Circuit, 16 April 2002).

The difficulties of enacting legislation in the USA and differences in legislation between the USA and the European Union indicate the subtle, but sometimes stark cultural and social contextualization not only of technology, but also of legal jurisdiction. Equally though, the apparent increasing harmonization of legal standards across the European Union indicates the force of increasing cooperation at sub-legal institutionalized levels.

\section{REGULATORY AGENCIES}

Monroe Price and Stephan Verhulst (2005: i) have claimed that ' $[\mathrm{t}]$ he Internet challenges classic patterns of regulation for both the identity of the rule makers and the instruments used to establish the rules of regulation' (see also Reidenberg (1996) quoted in Akdeniz (1997)). In part, this is certainly correct. The movements and mobilizations surrounding the introduction of the internet have led to a sea change in thinking about media and communications regulation (Verhulst, 2002). Many have talked about this shift, often with reference to the failure of the CDA, in terms of a move away from legal mechanisms of regulation toward more flexible forms of industry self-regulation. But there are various forms of self-regulation across different national and regional contexts and there are different understandings of whether self-regulation is viewed as a purely private market-based method of regulation (i.e. involving no form of statutory intervention) (Stein and Sinha, 2002) or as a form of network governance (i.e. sidestepping traditional state and market mechanisms) (Thompson, 2003; Collins, 2006). Yet, as Price and Verhulst (2005: 3) argue, '[s]elfregulation rarely exists without some relationship between the industry and the state', albeit 'a relationship that varies greatly': '[t]he actual meaning of self-regulation changes depending on the extent of government action, the history of the relationship between industry and government, and the nature of the public perceptions of the relationship between the private sector and the state'. As Tony Prosser has argued, 'in many cases selfregulatory techniques have been adopted to head off threats of government intervention' and there is a 'mixture of official regulation and self-regulation through public authorities specifying general standards or principles the implementation of which is delegated to firms themselves or trade associations' (Prosser, 2000: 103; Campbell, 2003). Historically the degree of independence of self-regulatory agencies is inversely related to their closeness (the degree of 'capture') to the sector that they regulate (Collins and Murroni, 1996: 176). Self-regulation is not separate from legal regulation, but rather operates in the context of statutory powers and law enforcement agencies. In the UK, for example, the Internet Watch Foundation (IWF) was formed in the context of the London Metropolitan Police threatening to arrest directors of ISPs and to confiscate property if they did not comply with demands for greater responsibility with regard to the circulation of child pornography on UK servers; and the IWF operates as a reporting and monitoring body only inasmuch as it is able both to call on ISPs to remove content suspected of being illegal and to pass on information regarding illegalities to law enforcement agencies (Akdeniz, 1997; Oswell, 1998b). In Australia, industry codes of practice and self-regulation sit in the context of Commonwealth, State and Territory 
legislation, and the Australian Communications and Media Authority (ACMA, formerly the Australian Broadcasting Authority (ABA) prior to July 2005) (Grainger, 1998; Electronic Frontiers Australia, 2006). Interdependencies exist across government control, industry selfregulation, and market governance (Verhulst, 2002; Price and Verhulst, 2005), not least to head off any 'generalized lack of public trust in the medium' (Programme in Comparative Media Law and Policy, 2005: 5), but also to frame 'trust' in the context of 'responsibility' and through historic issues concerning family welfare. In the absence of such interdependencies, it is possible, even likely, that industry would not be vigilant in policing itself nor know by what criteria it should do so (Campbell, 2003). Equally though, such semiautonomy (between state and industry) can be seen to occlude the mechanisms of power from public and democratic accountability (Starr, 2003). Nevertheless, despite some recognition of the rights of adults, a major lack of accountability of self-regulatory bodies may concern their lack of representation for those audiences that they claim to speak for and protect, namely children.

The condition of communication abundance has led to shifts in regulatory authority. Equally, increased visibility of social being as multi-cultural, multi-ethnic, and multi-faith across and within national and regional territories has led to uncertainty about enforcement of any common values (encoded through regulation), a questioning of statutory regulatory agencies, and the decentralization of regulatory authority to families. Such delegation of responsibility, though, is double-edged. The policing of children's media consumption is such that, on the one hand, there is a recognition that statutory bodies are unable to police cultural taste and 'harmful' content in the manner that was possible in the past with cinema, radio, and television and that, as a consequence, responsibility falls into the hands of parents; on the other hand, the making of parents responsible is caught up in historically devolved mechanisms for making those persons aware of their responsibilities and the criteria through which their responsibility might be judged by others (i.e. notions of 'good' and 'bad' parenting, 'normal' and 'pathological' families, and so on) (Oswell, 2002; Livingstone and Bober, 2004). Thus, any devolution of authority (in the context of moral, religious, and cultural value) is matched by a continuation and accentuation of historic forms of normalization (mediated by scientific and professionalized expertise) (Walkerdine and Lucey, 1989). Of course, the responsibilization of parents is often tied to the making of children into critical media consumers, such that the endowing of children with agency with regard to their media and communication use is seen to be able to offset any harm that such media might carry. In this sense, media literacy campaigns (often involving non-governmental organizations) addressed either to children or parents or both - have sought historically to readjust the balance between media and child (Lusted, 1985). Such strategies of responsibilization tend to displace the burden of risk downward and lead to a greater individualization of regulatory agency. Although not inevitable, there is a tendency for the reduction and management of risk to be left to individual parents or individual children (Programme in Comparative Media Law and Policy, 1999; Livingstone and Bober, 2004).

There is a strand of regulatory debate that has sought to make visible grass-roots communities (whether online or offline) as viable relays and resources for regulatory authority. Such an argument relies on viewing regulatory responsibility not simply as an individual or organisational duty, but as a social and collective act. For example, Adam Newey has argued that 'some notion of community is essential if we are to understand how to impose any effective regulation on the Internet'; Newey construes 'computermediated communities' as 'real social entities' in the 'real world' of 'local community': '[ $\mathrm{t}$ ] he network is rooted in a social context which, in the end, will determine the limits of acceptability' (Newey, 1999: 15, 30-31). An understanding of the power of communities to regulate themselves is found equally in more 
libertarian writers such as Barlow (1996b), who envisages forms of governance emerging from 'the commonweal', a community of 'lovers of freedom and self-determination', facing and resisting colonial and authoritarian power. Online community regulation may take the form of 'vigilante' groups - such as the Brazilian Anjos do Orkut or the US CyberAngels or the American Ethical Hackers against Pedophilia - attacking racehate and child pornography sites, whether verbally, through 'flaming', through viral and other software attacks or through surveying chatrooms and websites and reporting illegal material to ISPs and the police. It may also take the form of a governance within particular communities by recognized community regulators or activists. Matthew Williams has documented how those recognized as causing offence in the Cyberworlds community may be castigated online and even expelled from the collective: '[e]ffective online deviance reduction then lies in the balanced integration of community-led and formal modes of regulation' (Williams, 2006: 16).

\section{REGULATORY METHODOLOGIES}

Across the different regulatory agencies (statutory, industry, parent, child, and community) different methodologies of regulation are pursued. Although different mechanisms may be used in relation to different media and communications in different contexts, there are certain methodologies (prohibition, boundary marking and wall making, labelling and rating, reporting and monitoring, and empowerment) that are reiterated over time. Much discussion of content regulation from the early to late 1990s turned, on the one hand, on the seeming inadequacy of formal methods of censorship in the face of communication abundance and, on the other hand, on the perception that new legislation and regulatory technologies were themselves censorial. In response, there has been a marked shift away from a problematic of prohibition to consideration of more nuanced mechanisms of regulation. Christina Murroni and Nick Irvine
(1998: 78), for example, have argued that although it may be impossible to 'suppress' internet content, it is feasible to 'restrict' it to particular users. Nevertheless, as we have seen, many governments and regulatory agencies now consider the possibility of prohibiting production and distribution of, and access to, certain types of content (e.g. images of child sexual abuse and race-hate material) as a legitimate policy goal.

Murroni and Irvine (1998: 79) argue that ability to restrict access to particular content is dependent on the degree of privateness or publicness of a medium and whether access to content is likely to be accidental or voluntary. In this way a telephone conversation would constitute a private communication that can be restricted to voluntary users. In contrast, a billboard poster on a street corner is public and can be seen by anyone, whether they intend to see it or not. Some commentators have argued that because the internet is supposedly a public medium available to all (i.e. both adults and children), all the time, it should be heavily regulated in order to protect children and vulnerable persons (Wilson-Thomas, 1996). As discussed above, time, manner and place criteria have played a significant part in legislative discourse in the USA. They have also been a persistent feature of media and communications regulatory discourse, certainly, over the last 200 years. More recently, the placing of sexually explicit magazines on the 'top-shelf' of newsagent stalls, the establishment of $18 \mathrm{R}$ restricted video retail outlets for sexually explicit material in the UK, and the zoning of adult cinemas away from residential areas in the USA all demonstrate, in different ways, time, manner and place criteria. The zoning of internet content helps to construct a layering of architectures that ward off or encourage users; the ability to move across geography is dependent on the degree of access afforded to a user. As the degree of access hardens, boundary marking becomes less an issue of description of types of material (a relatively permeable membrane) than of thick walls that deny access to many (i.e. codified points of access, such as credit card restriction). 
But zoning is as much to do with repelling that which certain types of content are seen to attract (e.g. crime, antisocial behaviour, and so on) as with restricting access of certain persons. Moreover, the zoning of content occurs not only within cyberspace, but also in the relations across online and offline. There has been extensive research on the placing of media and communication technologies in 'public' (e.g. the sitting room) or 'private' (e.g. the bedroom) spaces in the home and on the temporal regularities of domestic media scheduling and use (Spigel, 1992; Oswell, 1999, 2002; Livingstone and Bovill, 2001). The architectures and geographies of media and communications become visible as governmental possibilities. Time and space become intelligible as the means for boundary marking and wall building. Time and space are mobilized in order to zone the geographies of media and communications. Such governmental architectures are more than code (Lessig, 1999).

Labelling and classificatory systems have been longstanding regulatory mechanisms. The BBC in the 1940s and 1950s considered on-screen labels and prior verbal warnings for certain types of content (notably at this time concerning close-up shots of teeth, ghosts, witches and 'figures with ghoulish faces' (Oswell, 2002)) and terrestrial television broadcasters in the UK have continued that tradition of forewarning viewers of potentially unsuitable content. Equally, the BBFC has classified content (including 'bad' language, sexual explicitness, and violence) according to normative age groups and such classifications are enforced through statutory legislation with regard to video and through local government powers with regard to cinema (the Cinematograph Act of 1909). Classificatory guidelines act in many ways as interpretative tools for consumers (parents, children, and others) to choose filmic material suitable to their own tastes and concerns (Buckingham, 1996). From the mid1990s, classificatory systems and technological means of enforcement have become a favoured regulatory mechanism with regard to communication abundance. The USA and
Canada adopted the 'V-chip' system, whereby rating levels can be set on the television set in the home and inappropriate content blocked thereafter. Some commentators have viewed the technology as overly authoritarian and claimed that it constructs parents 'as their children's enemy or drill sergeant, who must carry out the orders of the experts in order to control children and protect them from television' (Kapur, 1999: 122). Others though have argued that the demand for simple parameter settings for parents has meant that the competency threshold is such that children themselves are able to change the settings (Programme in Comparative Media Law and Policy, 1999: 4-5). There is substantial research to suggest that 'the V-chip has had little impact because of the lack of public knowledge of the meaning of the ratings, the existence of the V-chip and how to use it' (Campbell, 2003: 8; Kaiser Foundation, 2004). Nevertheless, labelling, rating, filtering and blocking technologies (such as PICS and RDF or Net Nanny and Cyber Patrol) have been developed with regard to internet communications. Recent classification and filtration systems analytically and functionally compress notions of labelling and rating, differentiate between labelling and filtering, and facilitate decentralized mechanisms for rating and blocking content. It is claimed, for example, by the Internet Content Rating Association (ICRA) that such functional differentiation allows for value-neutral labelling (ICRA, 2005). One of the problems with an abundance of content and content providers is that the task of classification is indefinite (inasmuch as content is constantly being produced and revised). If content is to be labelled, then such a task needs to be delegated downward. There can be no longer any centralized and totalizing vision of the allseeing censor. Censorship is now decentralized and localized. Labelling, though, is far from neutral; it makes possible the internet as 'regulable' (Negroponte, 1986; Lessig, 1998). Far from providing more nuanced mechanisms than the clumsy legislation of the CDA, filtering software may block access to content which is appropriate and legitimate 
and those providing such services are not democratically accountable (Lessig, 1998; Akdeniz, 2001).

The methodology of the hotline, similarly, delegates responsibility downward. It has been enthusiastically adopted, with regard to illegal internet content, in Europe (see INHOPE association of hotlines), the USA, and elsewhere since the mid-1990s (Williams, 1999). Hotlines (or 'tiplines'), such as Meldpunt Kinderporno in the Netherlands and the IWF in the UK, provide a means of allowing members of the public to report crime visible on the internet. Some hotlines are funded and run by government and some by industry or voluntary organizations; some cover only material hosted within their country, others material from across the globe; all are concerned with child pornography, and some also with race-hate and other material. In the past, statutory regulatory bodies (such as the Broadcasting Standards Commission in the UK) have been responsive to reports from the public as to particular issues around particular content (i.e. in the form of letters of complaint). But whereas the public in that respect was invited to complain about content they disliked or felt unsuitable, the public, with regard to internet hotlines, is constructed as a monitorial body that is able to survey the internet and report perceived illegalities accordingly. In this sense, members of the public are not invited to report in any personal capacity, but only in respect of their collective capacity as a form of modern policing. On the basis of reports from Australian citizens concerning perceived illegal content, ACMA, for example, is able to issue take-down notices to ISPs and to inform filtering and law enforcement agencies of prohibited content (Electronic Frontiers Australia, 2006: 5-7). In large part, the capacity of the public to report is dependent on the public visibility of such hotlines (i.e. media consumers need to know that there is a body to which to report issues), the communication of the types of content that come within its concern and of procedures for reporting by the public (i.e. the public need to know on what matters they might report and how to do so), and the public display of such a body in responding to and acting upon the views and reports of the public in ways appropriate and in keeping with that public (i.e. the public needs to view its reporting as an exercise of its power). But some have argued that 'illegality remains a matter to be decided by courts of law and not by private organizations or by quasi-regulatory bodies' (Akdeniz, 2001: 307).

Increasingly, regulatory agencies draw upon media education and media literacy campaigns as means to responsibilize and educate citizens as critical users (Grainger, 1998). The methodology of empowerment is defined not only with respect to providing parents and children with the capacity to prohibit or restrict access to certain content, but also to making users of internet content sufficiently robust as a means of defence against harm and to facilitate forms of sociality, bonding and mediation, that might mitigate against harm. Thus, although empowerment might mean that ' $[\mathrm{w}] \mathrm{e}$ will all become gatekeepers for content coming into our homes' (Ofcom, 2004; quoted in Livingstone and Bober, (2004: 7)), it also means that interpretative skills and greater talk about media use and content between different social actors (such as parents, children, non-governmental organizations and schools) become instituted as regulatory responses to communication abundance. Such a methodology can, in part, be seen as a response to greater visibility of children's rights, to changing understandings of the family as a democratic space (Livingstone, 2002), and to the historical development of children's critical media competencies (Oswell, 1998a, 2002).

\section{CONCLUSIONS}

Across the different regulatory agencies and methodologies, media and communications become visible to legal control and governance. We can, on the basis of existing evidence, offer some conclusions.

(a) For much of the nineteenth and twentieth centuries, although there were common themes and concerns (e.g. regarding 
violence, delinquency, national culture, and commercialism) across different media and communications, there were also clear asymmetries. The regulatory exigencies of radio were seen to be different from film or television or print. Where once different regulatory agencies and methodologies would have been spread over different industries and technologies and across different local, national and regional contexts, today we see an increasing demand for their standardization and location within centralized locales (such as the European Commission, ICRA, Ofcom). The imagined ease of translation across delivery systems and 'neutralization' of technological difference has led, in one sense at least, to a concentration of regulatory powers. The motor of regulatory convergence is not statutory legislation, but the sub-legal movements and assemblages of regulatory officials, non-governmental organizations, industry-hybrid associations, expert groups, and local, national, regional and transnational governmental bodies. Across the moments of social gathering of these actors, the regulatory languages and protocols, objectives and programmes, and legislative formalizations get problematized and articulated. These gatherings, statements, and actions constitute significant points of post-national governance.

(b) The internet has presaged not only a new age of complexity, but also a series of simplifications and centralizations of regulatory authority and power. Whereas once there was not a single table upon which all the regulatory problems and issues of all the different media and communications industries across all the different local, national and regional locales could be made visible, the 'internet' (as a discursive object) begins to provide such a totalizing space, a surface upon which all the cards can be laid and a new trans-media regulatory game is to be played. Regulatory convergence begins to constitute a single plane of understanding and problematization.

(c) Greater cognizance of national and cultural difference is a spur to greater harmonization and standardization of regulatory protocols, processes and forms of policing. The hotline and self-regulation are model responses to internet crime and child protection that have been spread and picked up rapidly since the mid-1990s (with regard to Malaysia and Lithuania, see Azmi (2004) and Kiškis and Petrauskas (2006)). They demonstrate a sharing of expertise across national jurisdictions. But they also constitute forms of interdependency. Regulation across national jurisdiction takes the form of serial linkage, of co-national organization, rather than overarching control.

(d) The convergence toward a singular plane of understanding is demonstrated in the shift from moral languages for regulation to scientific ones. This is not a new trend and has certainly been in evidence in other areas of social life since the nineteenth century. But in the field of child protection and media and communications, there has been (increasingly since the mid-twentieth century onward) expert explanation and public discussion of media 'panics' in scientific, rather than moral, terms. Regulatory bodies attempt to frame internet content in culturally neutral, normative terms.

(e) There is a greater reliance on 'blackboxed' regulatory technologies, such as filters and labelling standards. Regulatory models and protocols are encoded not simply in the human decision-making processes of organizations, but in computer software and hardware. Such encodings, as with the shift from moral to scientific languages, help to by-pass democratic debate and to seal regulation as an 'expert' field, out of reach from ordinary citizens.

(f) The devolution of regulatory authority downward is indicative of 'privatization' and 'responsibilization', rather than actual autonomy and control. Media-literate children, parental supervision, self-regulation, and legal mechanisms are not mutually exclusive techniques, but are co-extensive and interdependent.

(g) The black-boxing of regulatory technologies is not evidence of a 'superpanopticon' or more efficient and extensive surveillance and policing. Technologies of regulation are myopic. Regulatory agents only work with each other. 
(h) Technological developments become incitements for the extension of regulatory knowledge and the submission of communications to a singular plane of understanding. Regulatory problematization becomes a key stage in the process of making new forms of communication regulable. Temporal and spatial technological architectures become regulable and change in response.

In the broad spread of history, the texture, incommensurability, and asymmetry of media and communications governance of the past has given way to a greater instrumentalization of debate and regulatory mechanisms, a reduced universe of regulatory discourse, a greater convergence of regulatory domains and agencies, and a shifting of the burden of regulatory responsibility downward. That said, the shortsighted supervision of the regulator is both a curse and saving grace.

\section{REFERENCES}

Akdeniz, Y. (1997) 'Governance of pornography and child pornography on the global internet: a multilayered approach'. In L. Edwards and C. Waelde (eds) Law and the Internet: Regulating Cyberspace. Oxford: Hart Publishing; 223-241.

Akdeniz, Y. (2001) 'Internet content regulation: UK government and the control of internet content'. Computer Law and Security Report, 17(5).

Azmi, M.I. (2004) 'Content regulation in Malaysia: unleashing missiles on dangerous web sites'. Journal of Information, Law and Technology, (3). www2.warwick.ac.uk/fac/soc/law2/elj/jilt/2004_3/ azmi/[February 2006].

Barker, M. (1984a) A Haunt of Fears: The Strange History of the British Horror Comics Campaign. London: Pluto Press.

Barker, M. (ed.) (1984b) The Video Nasties: Freedom and Censorship in the Media. London: Pluto Press.

Barlow, J.P. (1996a) 'Thinking locally, acting globally'. www.eff.org//Misc/Publications/John_Perry_Barlow/? $\mathrm{f}=$ think_local_act_global_011596.article.txt [November 2006]. (Originally published in Time, 15 January 1996.)

Barlow, J.P. (1996b) A Declaration of the Independence of Cyberspace. http://homes.eff.org/ barlow/Declaration-Final.html [August 2007].

Blumler, J. and Biltereyst, D. (1998) The Integrity and Erosion of Public Television for Children:
A Pan-European Study. London: Broadcasting Standards Commission.

Buckingham, D. (1996) Moving Images: Understanding Children's Emotional Reponses to Television. Manchester: Manchester University Press.

Campbell, A. (2003) 'Self-regulation and the media: four years later'. Paper presented to the Programme on Comparative Media Law and Policy, Oxford University, 10 March.

Campbell, P. and Machet, E. (1999) 'European policy on regulation of content on the internet'. In J. Liberty (ed.) Liberating Cyberspace: Civil Liberties, Human Rights and the Internet. London: Pluto Press.

Childnet International (2001) Online Grooming and UK Law: A Submission by Childnet International to the Home Office. www.childnet-int.org/ downloads/online-grooming.pdf [November 2005].

Childnet International (2004) Children and Mobile Phones: An Agenda for Action. www.childnet-int.org/ downloads/CMPAAA_A4.pdf [October 2005].

Collins, R. (2006) 'Networks, markets and hierarchies. Governance and regulation of the UK internet'. Parliamentary Affairs, www.open.ac.uk/socialsciences/ staff/rcollins/networks_markets_hierarchies.pdf [November 2005].

Collins, R. and Murroni, C. (1996) New Media, New Policies: Media and Communications Strategies for the Future. Cambridge: Polity Press.

Commission of the European Communities (1996a) Communication on the Implications of the Information Society for European Union Policies - Preparing the Next Steps. Brussels: COM(96) 395; 24 July.

Commission of the European Communities (1996b) Green Paper on the Protection of Minors and Human Dignity in Audiovisual and Information Services. Brussels: COM(96) 483; 16 October.

Commission of the European Communities (1996c) Illegal and Harmful Content on the Internet. Brussels: COM(96)487; 16 October.

Commission of the European Communities (1997) Green Paper on the Convergence of the Telecommunications, Media and Information Technology Sectors and the Implications for Regulation: Towards and Information Society Approach. Brussels: COM(97)623; 3 December.

Commission of the European Communities (2005) Proposal for a Directive of the European Parliament and of the Council amending Council Directive 89/552/EEC. Brussels, $\operatorname{COM(2005)~} 646$ final 2005/0260 (COD); 13 December.

Cross, G. (1997) Kids' Stuff: Toys and the Changing World of American Childhood. Cambridge, MA: Harvard University Press.

Davies, M.M. and Corbett, B. (1997) The Provision of Children's Television in Britain: 1992-1996: 
An Enquiry for the Broadcasting Standards Commission. London: Broadcasting Standards Commission.

Drotner, K. (1988) English Children and their Magazines, 1751-1945. New Haven, CT: Yale University Press.

Drotner, K. (1992) 'Modernity and media panics' in Skovmand, Michael, and Schröder, Kim (eds.) Media Cultures. Reappraising Transnational Media. London: Routledge.

Electronic Frontiers Australia (2006) Internet Censorship in Australia. www.efa.org.au/Issues/Censor/Cens 1. html [February 2006].

Federal Communications Commission (1969) Federal Communications Commission Reports, 21(2d), 3 December.

Federal Communications Commission (1985) Federal Communications Commission Reports, 100(2d), 6 May.

Gardener, W. (2003) 'The Sexual Offences Bill: progress and the future'. In Tackling Sexual Grooming Conference, 29 September. www.childnet-int.org/ downloads/online-grooming2.pdf [November 2005].

Goode, E. and Ben-Yehuda, N. (1994) Moral Panics: The Social Construction of Deviance. Oxford: Blackwell.

Grainger, G. (1998) 'Freedom of expression and regulation of information in cyberspace: issues concerning potential international cooperation principles for cyberspace'. Speech to UNESCO International Congress, 1 September. www.aba.gov. au/newspubs/speeches/documents/ggmon98.pdf [November 2005].

Hall, S., Crichter, C., Jefferson, T., Clarke, J. and Roberts, B. (1978) Policing the Crisis: Mugging, the State and Law and Order. London: Macmillan.

Herman, E. and McChesney, R. (1997) The Global Media: The New Missionaries of Corporate Capitalism. London: Cassell.

High Level Group on the Information Society (1994) (Martin Bangemann, Chair) Europe and the Global Information Society: Recommendations to the European Council. Brussels: European Commission; 26 May.

Hills, J. and Michalis, M. (1999) 'Is convergence a purely European obsession?' Paper presented to the CCIS/Euricom Colloquium on The Political Economy of Convergence. London: University of Westminster.

Hooper, R. (2005) 'Content regulation in the multiplatform multichannel digital age'. Regulation in a Digital Environment Seminar, Hong Kong, August. Ofcom: www.ofcom.org.uk/media/speeches/ 2005/08/hk [January 2006].

ICRA (2005) ICRA Labelling System Specification. Internet Content Rating Association. http://www.icra.org/ systemspecification/ [February 2006].
Jordan, A. (1999) The Three-Hour Rule: Insiders' Reactions. Pennsylvania: Annenberg Public Policy Centre, University of Annenberg.

Kaiser Foundation (2004) Parents, Media and Public Policy. Washington: Kaiser Family Foundation.

Kapur, J. (1999) 'Out of control: television and the transformation of childhood in late capitalism'. In M. Kinder (ed.) Kids Media Culture. Durham, NC: Duke University Press.

Kiškis, M. and Petrauskas, R. (2006) 'Internet content regulation: implications for e-government'. Journal of Information, Law and Technology, (2-3). http://www2.warwick.ac.uk/fac/soc/law/elj/jilt/2005_ 2-3/kiskis-petrauskas/ [November 2005].

Kunkel, D. and Watkins, B. (1987) 'Evolution of children's television regulatory policy'. Journal of Broadcasting and Electronic Media, 31(4): 367-389.

Lessig, L. (1998) 'What things regulate speech: CDA 2.0 vs filtering'. Jurimetrics, 38: 629-670. (Draft available at www.cyber.harvard.edu/works/lessig/ what_things.pdf).

Lessig, L. (1999) Code and Other Laws of Cyberspace. New York: Basic Books.

Livingstone, S. (2002) Young People and New Media. London: Sage.

Livingstone, S. and Bober, M. (2004) 'Regulating the internet at home: contrasting the perspectives of children and parents'. http://www.lse.ac.uk/collections/ media@|se/pdf/SLstaff_page/Livingstone-Bober_ Regulating_the_internet_at_home.pdf [November 2005].

Livingstone, S. and Bovill, M. (2001) 'Bedroom culture and the privatization of media use'. In S. Livingstone and M. Bovill (eds) Children and their Changing Media Environment: A European Comparative Study. Hillsdale, NJ: Lawrence Erlbaum Associates.

Loader, B. (1997) 'The governance of cyberspace'. In B. Loader (ed.) The Governance of Cyberspace: Politics, Technology and Global Restructuring. London: Routledge.

Luke, C. (1990) Constructing the Child Viewer: A History of the American Discourse on Television and Children, 1950-1980. New York: Praeger.

Lusted, D. (1985) 'A history of suspicion: educational attitudes to television'. In D. Lusted and P. Drummond (eds) TV and Schooling. London: British Film Institute.

Melody, W. (2003) 'Can the Internet economy be governed and if so, how?' LSE Public Lecture, 1 May. www.lse.ac.uk/collections/LSEPublicLectures AndEvents/pdf/20030501Melody.pdf [November 2006].

Murroni, C. and Irvine, N. (1998) Access Matters. London: IPPR. 
Negroponte, N. (1986) Being Digital. London: Hodder and Stoughton.

Newburn, T. (1992) Permission and Regulation: Law and Morals in Post- War Britain. London: Routledge.

Newey, A. (1999) 'Freedom of expression: censorship in private hands'. In J. Liberty (ed.) Liberating Cyberspace: Civil Liberties, Human Rights and the Internet. London: Pluto Press.

Ofcom (2004) Ofcom's Strategy and Priorities for the Promotion of Media Literacy: A Statement. www.ofcom.org.uk [November 2005].

Oswell, D. (1998a) 'Early children's broadcasting in Britain, 1922-1964: programming for a liberal democracy'. Historical Journal of Film, Radio and Television, 18(3): 375-393.

Oswell, D. (1998b) "The Place of "childhood" in internet content regulation: a case study of policy in the UK'. International Journal of Cultural Studies, 1(2): 271-291.

Oswell, D. (1999) 'The dark side of cyberspace: internet content regulation and child protection'. Convergence, 5(4): 42-62.

Oswell, D. (2002) Television, Childhood and the Home: A History of the Making of the Child Television Audience in Britain. Oxford: Oxford University Press.

Oswell, D. (2006) 'When images matter: internet child pornography, forms of observation and an ethics of the virtual'. Information, Communication and Society, 9(2): 244-265.

Pearson, G. (1983) Hooligan: A History of Respectable Fears. London: Macmillan.

Programme in Comparative Media Law and Policy (1999) Final Report: Parental Control of Television Broadcasting. http://ec.europa.eu/avpolicy/info_centre/ library/studies/index_en.htm\#finalised [September 2007].

Programme in Comparative Media Law and Policy (2005) Internet Self-Regulation: An Overview. www.selfregulation.info/iapcoda/030329-selfregglobal-report.htm [November 2005].

Prosser, T. (2000) 'International lessons on law and regulation'. In T. Lees, S. Ralph and J. Langham Brown (eds) Is Regulation Still and Option in a Digital Universe? Luton: University of Luton Press.

Price, M. and Verhulst, S. (2005) Self-Regulation and the Internet. The Hague, The Netherlands: Kluwer Law International.

Reidenberg, J. (1996) 'Governing networks and cyberspace rule-making'. Emory Law Journal, 45: 911.
Rowland, W. (1997) 'Television violence redux: the continuing mythology of effects'. In M. Barker, and J. Petley (eds) III Effects: The Media/Violence Debate. London: Routledge.

Spigel, L. (1992) Make Room for TV. Chicago, IL: University of Chicago Press.

Starr, S. (2003) 'Responsible regulation'. Spiked, 23 July. www.spiked-online.com/Printable/00000006DE74. htm [February 2006].

Stein, L. and Sinha, N. (2002) 'New global media and communication policy: the role of the state in the twenty-first century'. In L. Lievrouw and S. Livingstone (eds) The Handbook of New Media. London: Sage.

Thompson, G. (2003) Between Hierarchies and Markets: The Logic and Limits of Network Forms of Organization. Oxford: Oxford University Press.

Tracey, M. and Morrison, D. (1979) Whitehouse. London: Macmillan.

Verhulst, S. (2002) 'About scarcities and intermediaries: the regulatory paradigm shift of digital content reviewed'. In L. Lievrouw and S. Livingstone (eds) The Handbook of New Media. London: Sage.

Walkerdine, V. and Lucey, H. (1989) Democracy in the Kitchen: Regulating Mothers and Socialising Daughters. London: Virago.

Wall, D. (2001) 'Cybercrime and the internet'. In D. Wall (ed.) Crime and the Internet. London: Routledge.

Wertham, F. (1954) Seduction of the Innocent. New York, Rinehart.

Williams, M. (2004) 'Cybercrime'. In J. Mitchell Miller (ed.) Encyclopaedia of Criminology. London: Routledge.

Williams, M. (2006) 'Policing and cybersociety: the maturation of regulation within an online community'. Policing and Society 16(4). www. cybercrimeresearch.com/Williams, \%20M\%20(2006)\% 20Policing\%20and\%20Cybersociety.pdf [February 2006].

Williams, N. (1999) The Contribution of Hotlines to Combating Child Pornography on the Internet. www.childnet-int.org/downloads/combating-childpornography.pdf [February 2006].

Wilson-Thomas, C. (1996) 'Report on legislation related to pornography and obscenity: the case for reform'. In Parliamentary All Party Family and Child Protection Group, Violence, Pornography and the Media, 25 June. 